\title{
CHARACTERIZATION OF RABIES VIRUS ISOLATED FROM A COLONY OF Eptesicus furinalis BATS IN BRAZIL
}

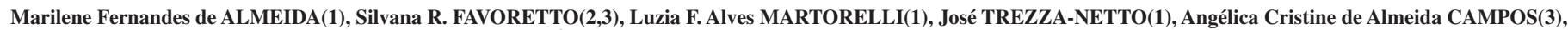
Carlos H. OZAhatA(4), Miriam Martos SODRÉ(1), Ana Paula A. G. KATAOKA(1), Débora R. Veiga SACRAMENTO(5) \& Edison L. DURIGON(3)

\begin{abstract}
SUMMARY
Some bat species have adapted to the expanding human population by acquiring the ability to roost in urban buildings, increasing the exposure risk for people and domestic animals, and consequently, the likelihood of transmitting rabies. Three dead bats were found in the yard of a house in an urban area of Jundiaí city in the state of São Paulo in southeast Brazil. Two of the three bats tested positive for rabies, using Fluorescent Antibody and Mouse Inoculation techniques. A large colony of Eptesicus furinalis was found in the house's attic, and of the 119 bats captured, four more tested positive for rabies. The objectives of this study were to report the rabies diagnosis, characterize the isolated virus antigenically and genetically, and study the epidemiology of the colony.
\end{abstract}

KEYWORDS: Rabies; Bats; Eptesicus furinalis; Antigenic typing; Genetic characterization.

\section{INTRODUCTION}

In countries where rabies in domestic animals is under control, the majority of human rabies deaths can be attributed to variants of the virus that are associated with bats, as verified by molecular studies ${ }^{11,15,17,36}$. In the United States from 1958 to 2000, 32 out of 35 human rabies cases were associated with variants specific to insectivorous bats ${ }^{15}$. Similarly, 148 out of 276 human rabies deaths in Latin America between 2004 and 2010, including 64 deaths in northern Brazil, were caused by contact with hematophagous bats ${ }^{1,4,23,29}$.

Improvements in canine vaccination programs and stray animal control in Brazil have led to a marked decrease in the incidence of rabies among humans. The number of canine rabies cases has also fallen steadily since 1980 , decreasing from greater than 170 cases to 17 cases in $2010^{23}$. Currently, the majority of human rabies cases in Brazil are caused by exposure to wildlife, including hematophagous bats (Desmodus rotundus), marmosets (Callithrix jacchus jacchus) and crab-eating foxes (Cerdocyon thous). Rabid bats have been documented in most of the Brazilian states, and rabies virus has been isolated from at least 41 of the 172 bats species that exist in Brazil ${ }^{2,31}$. Interestingly, 29 of the affected species have been observed to take refuge in houses and their surroundings ${ }^{34}$, increasing the risk of contact with people and domestic animals. According to data from the Pan-American Health Organization $^{23}$ (2010), among the 1,348 cases of rabies involving bats reported in Latin America between 2000 and 2010, 794 involved non-hematophagous bats $(58.9 \%)$, while 300 were in hematophagous bats $(22.3 \%)$. In the remaining 254 cases, the affected species was not characterized $(18.8 \%)$.

In São Paulo in southeast Brazil, the available data clearly demonstrate an increase in rabies case reporting in bats ${ }^{28}$. From 1985 to 1996, a total of 33 rabies-positive samples were obtained from bats, which is an average of three cases per year. From 1997 to 2010, 885 new specimens were diagnosed, corresponding to a 21 -fold increase in the number of cases per year to 63 cases in average. It remains a possibility that this increase in reported cases could be related to improvements in surveillance and registration, rather than an actual increase in the incidence of rabies in bats.

The objective of this study was to report the rabies diagnoses from a colony of Eptesicus furinalis (Argentine Brown Bat) from Jundiaí city, located in São Paulo State, Brazil. The virus obtained from the colony was characterized antigenically and genetically, and an epidemiological study was conducted. The results were then compared to data from different bat species throughout the Americas.

\section{MATERIAL AND METHODS}

E. furinalis bats were obtained from Jundiaí city (23ำ' $11^{\prime \prime}$, 4653'03”), São Paulo State, in southeast Brazil. Jundiaí is an urban center with 343,000 inhabitants covering an area of $432 \mathrm{~km}^{2}$. Rabies control measures, including vaccination campaigns and surveillance, are well-established in Jundiaí, and the last reported cases of rabies in humans and domestic animals occurred in 1979 and 1981, respectively.

(1) Centro de Controle de Zoonoses, Coordenação de Vigilância em Saúde/PMSP, São Paulo, SP, Brasil

(2) Laboratório de Diagnóstico do Instituto Pasteur de São Paulo, Secretaria Estadual da Saúde, São Paulo, SP, Brasil.

(3) Laboratório de Virologia Clinica e Molecular, Instituto de Ciências Biomédicas/Universidade de São Paulo, São Paulo, SP, Brasil.

(4) Seção de Controle de Zoonoses/Prefeitura do Município de Jundiaí, Jundiai, SP, Brasil.

(5) Genomic Engenharia Molecular, São Paulo, SP, Brasil.

Correspondence to: Marilene F Almeida, Phone: +55.11.2251-2666, Fax: +55.11.2251-2249. E-mail: marilene@ prefeitura.sp.gov.br 
ALMEIDA, M.F.; FAVORETTO, S.R.; MARTORELLI, L.F.A.; TREZZA-NETTO, J.; CAMPOS, A.C.A.; OZAHATA, C.H.; SODRÉ, M.M.; KATAOKA, A.P.A.G.; SACRAMENTO, D.R.V. \& DURIGON, E.L. - Characterization of rabies virus isolated from a colony of Eptesicus furinalis bats in Brazil. Rev. Inst. Med. Trop. São Paulo, 53(1): $31-7,2011$.

E. furinalis bats were identified according to their family, genus and species using the identification key proposed by VIZOTTO \& TADDEI ${ }^{37}$ (1973). Bats were anesthetized by injection of ketamine hydrochloride into the pectoral muscle (dose was dependent on the weight and volume). Animals were sacrificed in a $\mathrm{CO}_{2}$ chamber.

Rabies diagnoses were determined for brain smears using the Fluorescent Antibody Test ${ }^{6}$ (FAT) and the Mouse Inoculation Test ${ }^{12}$ (MIT) at the Rabies Laboratory in the Zoonoses Control Center in the city of São Paulo.

Antigenic characterization was performed as previously reported ${ }^{22}$, using a panel of eight monoclonal antibodies (MAb) against viral nucleoproteins. MAb were provided by the Centers for Disease Control and Prevention (CDC), Atlanta, USA.

Total RNA was extracted from infected bat brains with TRIzol ${ }^{\circledR}$ Reagent (Invitrogen, USA15596-26) according to the manufacturer's recommendations. RT-PCR was performed with primers $21 \mathrm{~g}$ (5' ATG TAA CAC CTC TAC AAT G 3', nt 55-73) and 304 (5' TTG ACG AAG TCT TGC TCA T 3', nt 1533-1514), which were specifically designed to amplify the rabies virus nucleoprotein as described by $\mathrm{SMITH}^{32}$ (1995). PCR products were purified using the Wizard PCR purification system (Promega, USA). Direct sequencing of the RT-PCR products was performed using the Big Dye Terminator Cycle Sequencing Ready Reaction Kit (Applied Biosystems Inc., USA).

A comparative phylogenetic study was undertaken using nucleotide sequences from different rabies variants collected from GenBank based on the 320-base-pair nucleoprotein gene located at position 1157 to 1476, according to PV strain (GenBank accession number NC_001542). Although the primer set amplifies nearly the complete $\mathrm{N}$ gene, the choice of this region was based on the number of sequences already available in GenBank, which are representative of rabies virus isolates found in bat populations and the terrestrial cycle in the Americas. The summary of rabies reference sequence data used is presented in Table 1. Vaccine strains, SAD B19 (M31046) and PV (NC_001542), were used for sequence comparison, and EBL-1 (U22845) and Duvenhage (EU293119) were included to serve as the out group to root the phylogenetic tree.

Alignment of multiple sequences was performed with BioEdit v7.0.9 (1197-2007, Tom Hall, Ibis Biosciences Carlsbad, CA), using the ClustalW method, which groups sequences into clusters by examining sequence distances between all pairs. Phylogenetic trees were constructed using the Neighbor-Joining (NJ) method with Kimura evolutionary distance correction statistics. The branching pattern was statistically evaluated by bootstrap analysis of 10,000 replicates in the program MEGA, version $4.0^{35}$. Bootstrap values are shown on the tree in Figure 1, which was obtained with the software FigTree v1.1.1 (2007-2008, Andrew Rambaut http://tree.bio.ed.ac.uk/software/figtree/).

\section{RESULTS}

In December 2004, three E. furinalis bats were found dead in the yard of a house. Two of them tested positive for rabies by FAT and MIT (one female and one male), while diagnosis of the third bat was not possible. The house was inspected, and a large colony of E. furinalis was discovered in the attic. The colony was composed of 119 bats that were captured with mist nets and identified as 32 young females, 49 adult females, 34 young males and seven adult males (including the first three specimens collected in the yard). Four more bats were positive for rabies using both techniques, three female and one male, all adults. More 64 houses in the neighborhood were inspected for the presence of bats, but no other colonies were discovered. The removal of the colony was conducted in accordance with the technical manual of São Paulo State ${ }^{26}$ (2003).

Table 1

Rabies virus nucleotide fragment used for comparative phylogenetic analysis

\begin{tabular}{llll}
\hline GenBank Acession & Host species & Country & Group \\
\hline AB117970 & Artibeus lituratus & Brazil & Group I - Related to Desmodus rotundus \\
AB117972 & Artibeus planirostris & Brazil & \\
AB201803 & Desmodus rotundus & Brazil & \\
AB201804 & Desmodus rotundus & Brazil & \\
AB201805 & Desmodus rotundus & Brazil & \\
AF070449 & Desmodus rotundus & Mexico & \\
AY877433 & Bovine & Mexico & \\
AY877434 & Equine & Brazil & \\
AB201810 & Eumops auripendulus & Brazil & \\
AB201817 & Molossus rufus & Mexico & Group II - Related to Tadarida brasiliensis \\
AY877435 & Bovine & Guyana & \\
EU293113 & Dog & USA & \\
AF394876 & Tadarida brasiliensis & Chile & \\
AF070450 & Tadarida brasiliensis & Argentina & \\
EU293116 & Tadarida brasiliensis & Argentina & Argentina \\
AY233426 & Tadarida brasiliensis & Tadarida brasiliensis & \\
AY233427 & &
\end{tabular}




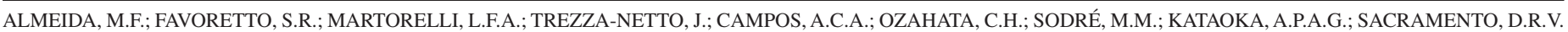
\& DURIGON, E.L. - Characterization of rabies virus isolated from a colony of Eptesicus furinalis bats in Brazil. Rev. Inst. Med. Trop. São Paulo, 53(1): 31-7, 2011.

Table 1

Rabies virus nucleotide fragment used for comparative phylogenetic analysis (cont.)

\begin{tabular}{|c|c|c|c|}
\hline GenBank Acession & Host species & Country & Group \\
\hline AY233449 & Myotis sp. & Argentina & Group III - Related to others insectivorous bats \\
\hline AY233450 & Myotis nigricans & Argentina & \\
\hline AB201811 & Eptesicus furinalis & Brazil & \\
\hline AB201812 & Eptesicus furinalis & Brazil & \\
\hline AB201813 & Eptesicus furinalis & Brazil & \\
\hline AB201814 & Eptesicus furinalis & Brazil & \\
\hline AB201809 & Eumops auripendulus & Brazil & \\
\hline AB201807 & Nyctinompos laticaudatus & Brazil & \\
\hline AF394887 & Eptesicus fuscus & USA & \\
\hline AF394888 & Eptesicus fuscus & USA & \\
\hline AY170397 & Eptesicus fuscus & USA & \\
\hline AY039226 & Eptesicus fuscus & USA & \\
\hline AY039227 & Eptesicus fuscus & USA & \\
\hline AY039229 & Eptesicus fuscus & USA & \\
\hline AF394873 & Myotis californicus & USA & \\
\hline AF394874 & Myotis evotis & USA & \\
\hline AB201815 & Molossus molossus & Brazil & \\
\hline AB201816 & Molossus molossus & Brazil & \\
\hline AB201808 & Nyctinomops laticaudatus & Brazil & Group IV - Related to Nyctinomops sp. \\
\hline EU873001 & Cat & Brazil & \\
\hline AB201806 & Nyctinomops laticaudatus & Brazil & \\
\hline AF533780 & Histiotus sp. & Chile & Group V - Related to Histiotus sp. \\
\hline AF533812 & Histiotus sp. & Chile & \\
\hline AY233448 & Histiotus montanus & Argentina & \\
\hline DQ631835 & Eptesicus furinalis & Brazil & This study \\
\hline DQ631836 & Eptesicus furinalis & Brazil & \\
\hline DQ631837 & Eptesicus furinalis & Brazil & \\
\hline DQ631838 & Eptesicus furinalis & Brazil & \\
\hline DQ631839 & Eptesicus furinalis & Brazil & \\
\hline AY233451 & Tadarida brasiliensis & Argentina & Group VI - Related to genus Lasiurus and Lasionycteris \\
\hline AF394886 & Lasiurus borealis & USA & \\
\hline AY705373 & Lasionycteris noctivagans & USA & \\
\hline AY654585 & Human & Brazil & Related to Brazilian Marmosets \\
\hline AY654586 & Callithrix jacchus & Brazil & \\
\hline AY654587 & Human & Brazil & \\
\hline DQ447947 & Human & Brazil & Terrestrial Cycle \\
\hline DQ447948 & Cerdocyon thous & Brazil & \\
\hline DQ447966 & Human & Brazil & \\
\hline DQ447968 & Human & Brazil & \\
\hline EF194167 & Dog & Brazil & \\
\hline AY233414 & Dog & Argentina & \\
\hline AY340785 & Dog & Bolivia & \\
\hline NC_001542 & PV - Vaccine strain & France & \\
\hline M31046 & SAD_B19 Vaccine strain & Germany & \\
\hline U22845 & EBLvfr320_1989_Eptesicus serotinus & France & Out Group \\
\hline EU293119 & DUVv_1971_Human & South Africa & \\
\hline
\end{tabular}




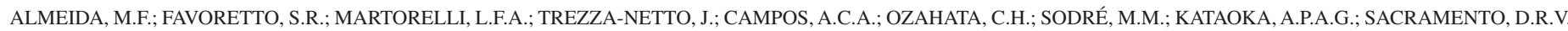
\& DURIGON, E.L. - Characterization of rabies virus isolated from a colony of Eptesicus furinalis bats in Brazil. Rev. Inst. Med. Trop. São Paulo, 53(1): 31-7, 2011.

Of the six positive samples, five were available for antigenic and genetic characterization. Antigenic characterization of the isolates revealed a single distinct reaction pattern $(\mathrm{C} 4+\mathrm{C} 10+\mathrm{C} 12+)$. The region of the genome used to analyze the relationship among strains have been previously evaluated and found to be informative for epidemiological studies $^{9}$. A portion of the amplified nucleoprotein gene was excluded from the analysis, due to the absence of this region in the majority of the chosen representative sequences.

The nucleotide sequences of the five E. furinalis samples were reported to GenBank (accession numbers DQ631835-DQ631839). The phylogenetic topology tree shows 12 distinct clades: one clade related to terrestrial epidemiological cycle of transmission (clade 12), 10 clades related to aerial epidemiological cycle of transmission maintained by bats population formed by clades from 1 to 10 and an independent one clade 11 corresponding to lineage maintained in Brazilian marmosets (Fig. 1).

The E. furinalis samples shared a high degree of similarity, with $99.0 \%$ to $100.0 \%$ intrinsic genetic identity, as is expected for isolates from the same colony. These sequences formed a distinct monophyletic clade that was statistically supported by high bootstrap values. When compared to other Brazilian isolates from E. furinalis (AB201811, AB201812, AB201813, AB201814), a distinct clade was observed, but with only $86.1 \%$ similarity (Fig. 1, Table 1).

The average pairwise nucleotide identity among rabies viruses related to bats ranges from $85.9 \%$ to $93.6 \%$, with the highest percentage occurring among the Brazilian groups of insectivorous bats, such as Histiotus sp. (93.6\%) and Nyctinomops laticaudatus (90.3\%). The lowest percent identity occurred within $D$. rotundus bats $(85.9 \%)$. Even lower identities were observed for the groups formed by the Brazilian marmoset variant $(81.2 \%)$ and the terrestrial group (78.4\%). We were unable to determine a clustering correlation between different samples within the terrestrial cycle of transmission, including the vaccine strains (PV and SAD-B19).

\section{DISCUSSION}

E. furinalis bats are colonial, non-migratory and insectivorous, and they can be found in a variety of habitats that includes human dwellings. Colonies of up to 100 bats have been reported in ceilings of houses and yards ${ }^{16}$. E. furinalis can live as long as 19 years, and females give birth to two offspring per year. During the reproduction period, the bats form maternity colonies, with the males remaining alone or in small groups ${ }^{20}$. This could explain the predominance of females observed in the colony from which we collected samples.

Although no human rabies cases associated with insectivorous bat have been reported in Brazil, these bats are known to be reservoirs for the rabies viruses throughout the Americas. Insectivorous bats are attracted to urban areas by the insect population, which is attracted to street lamps ${ }^{25}$. Changes in the landscape due to urban and suburban housing developments may further restrict both the roosting and foraging habitats of bats. In addition, urban ecosystems offer large amounts of food and roosts (attics, roofs, basements, etc.) associated with a lack of predators. Consequently, some bat species have adapted to roosting in buildings ${ }^{13}$. Although insectivorous bats are useful in controlling nocturnal flying insects $^{24}$ and other invertebrates that can negatively impact agriculture ${ }^{33}$, people frequently complain about the presence of bats because of the noise they make and the odor of their urine and excrement ${ }^{27}$.

The prevalence of the rabies virus within a bat population is very difficult to determine, and in the majority of bat-derived rabies cases, the colony is never located. The case reported here provided a unique opportunity because the shelter and the colony were discovered.

Antigenic characterization was performed by comparison of the monoclonal reaction pattern with the 11 pre-established reactivity profiles characteristic of rabies variants isolated from animals involved with rabies virus maintenance and transmission in Latin America. The antigenic profile observed $(\mathrm{C} 4+, \mathrm{C} 10+, \mathrm{C} 12+)$ was not compatible with the pre-established profiles in this panel. However, the same positive reaction profile has already been detected in samples isolated from a cat, a Cerdocyon thous (crab-eating fox) and in the insectivorous bat Eumops auripendulus ${ }^{8}$. Moreover, CASTILHO ${ }^{2}$ et al. (2008) reported the same positive reaction in specimens of E. furinalis, Eumops perotis and Eumops auripendulus.

The epidemiology of rabies in the Americas is highly complex, particularly with respect to the role played by insectivorous bats, which has been investigated in several studies ${ }^{3,7,18,21,36}$. Passive surveillance and molecular epidemiological studies have revealed multiple independent cycles and an expressive diversity of rabies genetic variants maintained in these species. Until now, all characterized viruses have belonged to Rabies virus species, and high homology was observed among rabies from insectivorous bats. Furthermore, the viruses isolated thus far have been more closely related to samples derived from North American bats than they have to vampire bats ${ }^{5}$. The same results were observed for the samples investigated in this study.

The five isolates segregated into a monophyletic cluster as expected because they are from the same colony. However, $16.0 \%$ divergence was observed relative to other Brazilian isolates from the same species. Thus, two phylogenetically distinct lineages of rabies virus are circulating in Brazilian E. furinalis bats within the same state (São Paulo), approximately 380 kilometers from each other. Geographical distribution and non-migratory behavior could explain this fact. The possibility of determining species-specific viral variants for $E$. furinalis has been discussed previously; however, that particular variant was isolated from Nyctinomops laticaudatus and E. auripendulus ${ }^{10}$. Our study demonstrates the existence of an additional variant isolated from $E$. furinalis. Because of the low number of samples analyzed in this study, we cannot confirm that the variants observed in E. furinalis are species-specific, and the same is true for the study by KOBAYASHI ${ }^{10}$ et al. (2005). Interestingly, our analysis suggests that virus lineage is associated with the biome where the host was found. The Brazilian E. furinalis came from an urban area in the city of Jundiaí, while the bats studied by KOBAYASHI ${ }^{10}$ et al. (2005) were collected from a distinct biome in a predominantly rural area with extensive ranching.

A similar case of two rabies lineages circulating in the same species was also observed for E. fuscus by NADIN-DAVIS ${ }^{17}$ et al. (2001). However, it is not possible to relate the results of our study to bat behavior, as discussed by NADIN-DAVIS ${ }^{17}$ et al. (2001) and DAVIS ${ }^{5}$ et al. (2006), because Brazilian E. furinalis bats are not migratory. Another possible explanation for our results would be if different mitochondrial lineages 
ALMEIDA, M.F.; FAVORETTO, S.R.; MARTORELLI, L.F.A.; TREZZA-NETTO, J.; CAMPOS, A.C.A.; OZAHATA, C.H.; SODRÉ, M.M.; KATAOKA, A.P.A.G.; SACRAMENTO, D.R.V. \& DURIGON, E.L. - Characterization of rabies virus isolated from a colony of Eptesicus furinalis bats in Brazil. Rev. Inst. Med. Trop. São Paulo, 53(1): 31-7, 2011.

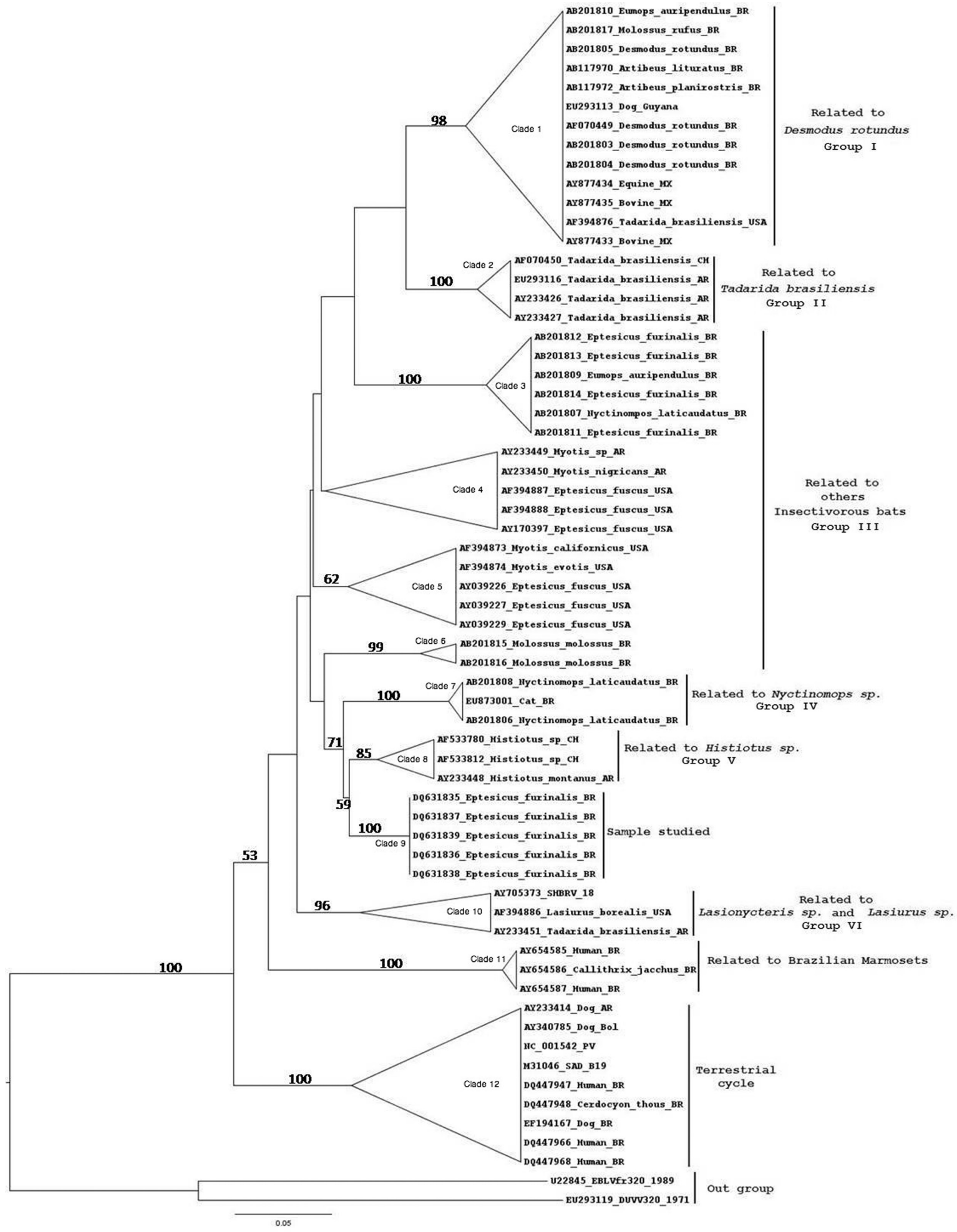

18 set09

Fig. 1 - Maximum likelihood (ML) phylogenetic tree, reconstructed with MEGA 4.0 software and a Neighbor-Joining (NJ) algorithm with a heuristic search. Bootstrap analysis with 10,000 replicates was performed by MEGA 4.0 software. Topology was performed with FigTree software. The tree showing a comparison of the clades and groups formed by nucleotide sequences of American samples obtained from GenBank, two vaccine strains: PV (NC_001542) and SAD-B19 (M31046), and the five samples studied. The out group was formed by EBLV (U22845) and DUVV (EU293119). 
ALMEIDA, M.F.; FAVORETTO, S.R.; MARTORELLI, L.F.A.; TREZZA-NETTO, J.; CAMPOS, A.C.A.; OZAHATA, C.H.; SODRÉ, M.M.; KATAOKA, A.P.A.G.; SACRAMENTO, D.R.V. \& DURIGON, E.L. - Characterization of rabies virus isolated from a colony of Eptesicus furinalis bats in Brazil. Rev. Inst. Med. Trop. São Paulo, 53(1): $31-7,2011$.

did exist for $E$. furinalis, as was suggested for $E$. fuscus by NEUBAUM ${ }^{19}$ et al. (2008) and for D. rotundus by MARTINS ${ }^{14}$ et al. (2007).

The phylogenetic analysis showed only $85.9 \%$ similarity between the isolates from the E. furinalis colony and the clade containing viral variants from hematophagous bat populations, pets and herbivorous, non-

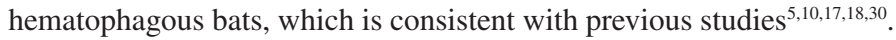
However, the segment of the rabies genome used to reconstruct the phylogenetic trees in this study is different from those used in the abovementioned studies, and therefore, some sequences occupied different positions.

The colony of $E$. furinalis studied here was roosting in the attic of a house in an urban area. A family had been living in the house for nearly three years, although according to the neighbors, no previous residents had occupied the house for seven or eight years before this family moved in. There were 64 habitable houses in the neighborhood, providing ample opportunities for accidental contact between the bats and domestic animals or people, especially children. The risk of rabies reemerging among domestic animals has already been demonstrated by the isolation of rabies variants specific to insectivorous bats from domestic animals, such as cats s,18,36. $^{8}$.

In urban areas where rabies in dogs has been controlled, reports of rabies harbored by bat species have generally increased. Further research is required to characterize the biology and behavior of bats in urban settings, and the precise identification of the bat species involved is essential for determining the role that these species play in the epidemiology of rabies.

\section{RESUMO}

\section{Caracterização do vírus da raiva isolado de uma colônia de morcegos Eptesicus furinalis, do Brasil}

Algumas espécies de morcegos têm se adaptado ao uso de abrigos em construções urbanas, aumentando a possibilidade de contato desses morcegos com pessoas e animais domésticos e conseqüentemente, o potencial risco de transmissão de raiva. Três morcegos foram encontrados no jardim de uma casa na área urbana da cidade de Jundiaí, Estado de São Paulo, Sudeste do Brasil, dois deles foram positivos para raiva pelas técnicas de imunofluorescência e inoculação em camundongos. Uma grande colônia de E. furinalis foi identificada, vivendo no sótão da casa e 119 morcegos foram encaminhados para diagnóstico de raiva, com mais quatro morcegos positivos. O objetivo desse estudo é apresentar a caracterização genética e antigênica do vírus da raiva isolado desses morcegos e o estudo epidemiológico da colônia.

\section{REFERENCES}

1. Barbosa TF, Medeiros DB, Travassos da Rosa ES, Casseb LM, Medeiros R, Pereira AS, et al. Molecular epidemiology of rabies virus isolated from different sources during a bat-transmitted human outbreak occurring in Augusto Correa municipality, Brazilian Amazon. Virology. 2008;370:228-36

2. Castilho JG, Canello FM, Scheffer KC, Achkar SM, Carrieri ML, Kotait I. Antigenic and genetic characterization of the first rabies virus isolated from the bat Eumops perotis in Brazil. Rev Inst Med Trop Sao Paulo. 2008;50:95-9.
3. Cisterna D, Bonaventura R, Caillou S, Pozo O, Andreau ML, Fontana LD, et al. Antigenic and molecular characterization of rabies virus in Argentina. Virus Res. 2005;109:13947.

4. Da Rosa, ES, Kotait I, Barbosa TF, Carrieri ML, Brandão PE, Pinheiro AS, et al. Bat-transmitted human rabies outbreaks, Brazilian Amazon. Emerg Infect Dis. 2006;12:1197-202

5. Davis PL, Bourhy H, Holmes EC. The evolutionary history and dynamics of bat rabies virus. Infect Genet Evol. 2006;6:464-73.

6. Dean DJ, Abelseth MK, Atanasiu P. The fluorescent antibody test. In: Meslin FX, Kaplan MM, Koprowski H, editors. Laboratory techniques in rabies. $4^{\text {th }}$ ed. Geneva: WHO; 1996. p. 88-95.

7. De Mattos CA, Favi M, Yung V, Pavletic C, de Mattos CC. Bat rabies in urban centers in Chile. J Wild Diseases. 2000;36:231-40.

8. Favoretto SR, Carrieri ML, Cunha EMS, Aguiar EAC, Silva LHQ, Sodré MM, et al. Antigenic typing of Brazilian rabies virus samples isolated from animals and humans, 1989-2000. Rev Inst Med Trop Sao Paulo. 2002;44:91-5.

9. Kissi B, Tordo N, Bourhy H. Genetic polymorphism in the rabies virus nucleoprotein gene. Virology. 1995;209:526-37.

10. Kobayashi Y, Sato G, Shoji Y, Sato T, Itou T, Cunha EM, et al. Molecular epidemiological analysis of bat rabies viruses in Brazil. J Vet Med Sci. 2005;67:647-52.

11. Kobayashi Y, Sato G, Kato M, Itou T, Cunha EM, Silva MV, et al. Genetic diversity of bat rabies viruses in Brazil. Arch Virol. 2007;152:1995-2004.

12. Koprowski H. The mouse inoculation test. In: Kaplan MM, Koprowski H, Meslin FX, editors. Laboratory techniques in rabies. $4^{\text {th }}$ ed. Geneva: WHO; 1996. p. 80-6.

13. Kunz TH.. Roosting ecology of bats. In: Kunz TH, editor. Ecology of bats. New York: Plenum Press; 1982. p. 1-55.

14. Martins FM, Ditchfield AD, Meyer D, Morgante JS. Mitochondrial DNA phylogeography reveals marked population structure in the common vampire bat, Desmodus rotundus (Phyllostomidae). J Zoolog Syst Evol Res. 2007;45:372-8.

15. Messenger SL, Smith JS, Ruprecht CE. Emerging epidemiology of bat-associated cryptic cases of rabies in humans in the United States. Clin Infect Dis. 2002;35:738-47.

16. Mies R, Kurta A, King DG. Eptesicus furinalis. Mammalian species. 1996;526:1-7.

17. Nadin-Davis SA, Huang W, Armstrong J, Casey GA, Bahloul C, Tordo N, et al. Antigenic and genetic divergence of rabies viruses from bat species indigenous to Canada. Virus Res. 2001;74:139-56

18. Nadin-Davis SA, Loza-Rubio E. The molecular epidemiology of rabies associated with chiropteran hosts in Mexico. Virus Res. 2006;117:215-26.

19. Neubaum MA, Shankar V, Douglas MR, Douglas ME, O'Shea TJ, Rupprecht CE. An analysis of correspondence between unique rabies virus variants and divergent big brown bat (Eptesicus fuscus) mitochondrial DNA lineages. Arch Virol. 2008;153:1139-42.

20. Nowak RM. Walker`s mammals of the world. Baltimore: John Hopkins University Press; 1991.

21. Páez A, Nuñez C, García C, Bóshell J. Molecular epidemiology of rabies epizootics in Colombia: evidence for human and dog rabies associated with bats. J Gen Virol. 2003; $84: 795-802$.

22. Pan-American Health Organization. Los anticuerpos monoclonales en la caracterización y vigilancia de los virus de la rabia en América Latina y el Caribe. Pan Am J Public Health. 2000;8:214-7. 
ALMEIDA, M.F.; FAVORETTO, S.R.; MARTORELLI, L.F.A.; TREZZA-NETTO, J.; CAMPOS, A.C.A.; OZAHATA, C.H.; SODRÉ, M.M.; KATAOKA, A.P.A.G.; SACRAMENTO, D.R.V. \& DURIGON, E.L. - Characterization of rabies virus isolated from a colony of Eptesicus furinalis bats in Brazil. Rev. Inst. Med. Trop. São Paulo, 53(1): 31-7, 2011.

23. Pan-American Health Organization. Panaftosa. [cited 2010]. Available from: http://siepi. panaftosa.org.br/anuais.aspx and http://sirvera.panaftosa.org.br

24. Reis NR, Lima IP, Peracchi AL. Morcegos (Chiroptera) da área urbana de Londrina, Paraná, Brasil. Rev Bras Zool. 2002;19:739-46.

25. Rydell J, Racey PA. Street lamps and the feeding ecology of insectivorous bats. Symposium Zoological Society of London. 1995;67:291-307.

26. São Paulo. Manejo de Quirópteros em áreas urbanas. São Paulo: Secretaria da Saúde do Estado de São Paulo; 2003. n 7.

27. São Paulo. Laboratório de identificação e pesquisa em fauna sinantrópica. São Paulo: Secretaria Municipal da Saúde, Coordenação de Vigilância em Saúde; 2004. Revista da Vigilância em Saúde Ambiental. p 64-73.

28. São Paulo. Informes da Coordenação do Programa de Controle da Raiva do Estado São Paulo-1997 a 2007. 2008

29. Schneider MC, Romijn PC, Uieda W, Tamayo H, da Silva DF, Belotto A, et al. Rabies transmitted by vampire bats to humans: an emerging zoonotic disease in Latin America? Rev Panam Salud Publica. 2009;25:260-9.

30. Shoji Y, Kobayashi Y, Sato G, Gomes AA, Itou T, Ito FH, et al. Genetic and phylogenetic characterization of rabies virus isolates from wildlife and livestock in Paraiba, Brazil Acta Virol. 2006;50:33-37.
31. Sodré MM, Gama AR, Almeida MF. Updated list of bats species positive for rabies in Brazil. Rev Inst Med Trop Sao Paulo 2010;52:75-81.

32. Smith JS. Rabies virus. In: Murray PR, Baron EJ, Pfaller MA, Tenover FC, Yolken R, editors. Manual of clinical Microbiology. Washington: American Society for Microbiology Press; 1995. p. 997-1003.

33. Swier VJ. Distribution, roost site selection and food habits of bats in Eastern South Dakota. [dissertation]. Dakota: South Dakota State University; 2003.

34. Taddei VA. Sistemática de quirópteros. Bol Inst Pasteur São Paulo. 1996;1:3-15.

35. Tamura K, Dudley J, Nei M, Kumar S. MEGA4: Molecular Evolutionary Genetics Analysis (MEGA) software version 4.0. Mol Biol Evol. 2007;24:1596-9.

36. Velasco-Villa A, Orciari LA, Juárez-Islas V, Gómez-Sierra M, Padilla-Medina I, Flisser A, et al. Molecular diversity of rabies viruses associated with bats in Mexico and other countries of the Americas. J Clin Microbiol. 2006;44:1697-710.

37. Vizotto LD, Taddei VA. Chave para determinação de quirópteros brasileiros. Rev Fac Filos Cien Letr S José R Preto Bol Cienc. 1973;1:1-72.

Received: 17 December 2009

Accepted: 8 October 2010 